\title{
Project Management: Key Initiatives Case Study
}

\author{
Khaled Al Nass \\ kalnaas@ccc.net \\ CCC, Doha, Qatar \\ Lavinia Melilla \\ Lavinia.melilla@arcadis.com \\ Arcadis, Doha, Qatar \\ Mohamed Tolba \\ mtolba@ashghal.gov.qa \\ Public Works Authority (Ashghal), Doha, Qatar
}

\begin{abstract}
Every project faces risk of delays and disruptions, especially the mega/complex projects of today, which have, amongst others, many interfacing parties engaged. Local roads and drainage projects in general, including DN016, can be considered complex projects due to a number of reasons such as, a) working in residential areas, b) deep excavations, c) number of interfacing parties, d) project duration, e) multifaceted identification for the location of existing underground utilities. The contractor decided to use some tools to help minimize the negative impacts of a number of challenges such as, 1) workface planning by dividing the project into 5 zones and start working in free zones for early zone handover, 2) lean construction to minimize the waste, 3) management processes in order to control the known-unknown challenges and risks and to minimize those and 4) Building Information Model (BIM) for the identification of major and minor clashes to the designer in order to resolve them early as to have a smooth construction flow. In addition, the project management team identified both internal and external stakeholders of the project in order to determine the project requirements and expectations of all parties involved. A dedicated stakeholder manager was appointed to identify and manage the stakeholder issues without affecting the project performance. Although major efforts are done in this regard, many stakeholders residing nearby the construction area are negatively affected from the project execution due to the nature of the project and time constraints. The supervision consultant and the client also directly engaged in managing the stakeholders and ultimately impacted the project. However, further delays were mitigated with the implementation of regular stakeholders' meetings, and work was carried over based on their requirements. Also, the project management decided to have a handing over plan from early stages of the project and to assign a dedicated handing over manager with required resources, and mobilize them very early in the project. The handing over team identified all the handing over procedures and the required documentation with the client.
\end{abstract}

Keywords: Planning; Workface; Lean construction; Building Information Model (BIM); Risk; Infrastructure

\section{INTRODUCTION}

Bani Hajer North Phase 2 is part of Ashghal local roads network projects designed at improving the wider infrastructures architecture in the State of Qatar. Roads and infrastructure works in Bani Hajer residential area consist of roads with around 163,000 M2 providing utility services like surface water drainage of length 39,121 and 7 No. 
of attenuation tanks with 3,038 LM of micro tunnelling works, TSE network, street lighting, ITS, telecommunication network and landscaping works. The project duration is 16 months with a value of QAR323 million.

\section{KEY PROJECT INTIATIVES}

The project management has implemented key project initiatives and effectively managed issues throughout the project execution phases. This document outlines the measures and key initiatives that have been implemented for the successful completion of the project:

- $\quad$ Project planning

- Lean construction implementation

- Risk management plan

- Stakeholder management

- Handing over plan

Although these are known project management techniques, the project has utilised and implemented them effectively to mitigate the risk of delays in the project.

\subsection{Project planning}

The baseline program has been developed for the project, explaining the project construction sequence of works from the date of commencement to completion. The document shows all the coding and work breakdown structure of the schedule from several points of view by highlighting the critical path(s), and the key intermediate milestones. The early part of the project covers the engineering and procurement phases and then the construction phase as well. The schedule ensures the alignment of the engineering and procurement deliverables with the construction sequence.

The project begins with setup and interactive planning to define the optimum construction schedule. The plot plan is broken into Construction Work Areas (CWAs) which are further divided into discipline specific Construction Work Packages (CWPs). Engineering deliverables as EWP (Engineering Work Package) and procurement items as PWP (Procurement Work Package) are defined for each CWP. The CWP sequence defines the timing for development and sequential delivery of engineering and procurement. This helps to organize and deliver all the elements necessary, before the work is started, to enable craft persons to perform quality work in a safe, effective, and efficient manner. This type of planning is defined as Workface Planning or Advanced Work Packaging.

Construction Industry Institute (CII) defines Advanced Work Packaging (AWP) as, "the overall process flow of all the detailed work packages (construction, engineering, and installation work packages). AWP is a planned, executable process that encompasses the work on EPC project, beginning with initial planning and continuing through detailed design and construction execution. AWP provides the framework for productive and progressive construction, and presumes the existence of a construction execution plan."

The construction activities and durations are defined from estimated quantities and preliminary estimates and applying reasonable production rates (based on experience in Qatar) mainly to determine durations.

The utilities storm water drainage, foul sewer, TSE, ITS, Q-Tel, DSSS is grouped into the road works and the scope is detailed for each utility network under the WBS. 
The project is divided into five zones. All the roads are grouped into respective zones. The roads are further divided into single phase construction for new roads and two phase constructions for the existing roads.

The single phase construction roads which are new roads are planned to commence immediately once the drawings are submitted and approved. The two phase construction roads with existing traffic are planned to commence once the traffic management plans are submitted and approved for construction.

The project critical path runs on most of the two-phase roads as these needs traffic diversions. The project management identifies that the duration of the project is not enough to complete the project on time considering the criticality of the utilities scope and the sequence of works.

\subsection{Lean construction}

The following lean concepts implemented in the project are as follows:

A. Construction planning

(i) Utilizing BIM 3D model

(ii) Utilizing clash analysis -BIM model

B. Project execution performance

(i) Issue three months look-ahead

(ii) Identify pre-requisites for the look ahead activities in advance

(iii) Measure the performance of 3 months look ahead- KPIs

(iv) Identify the root causes of the deficiency activities

C. Project execution monitoring and control

(i) Measure the productivities of the direct resources

(ii) Identify root causes for deficiencies

(iii) Target for continuous improvement

(iv) Reduce construction waste

D. Project handing over

(i) Link RFIs to BIM 3D model

(ii) Internal software - ATLAS for handing over

The project planning team utilised the 3D BIM model to analyse the scope of work in detail. Without the use of BIM, the complexity of the underground utilities in the local roads projects cannot be estimated properly in terms of the typical section and the sequence of works.

Salman Azhar (2011) states that, "Building Information Modelling (BIM) is one of the most promising recent developments in the Architecture, Engineering, and Construction (AEC) industry. With BIM technology, an accurate virtual model of a building is digitally constructed. This model, known as a building information model, can be used for planning, design, construction, and operation of the facility. It helps architects, engineers, and constructors visualize what is to be built in a simulated environment to identify any potential design, construction, or operational issues. BIM represents a new paradigm within AEC, one that encourages integration of the roles of all stakeholders on a project."

The project management team resolves the utility clashes using BIM before the works 
commencing on site. This tool helped avoiding delays in the completion of utilities. The clashes were identified as major, which require design change, and minor, which can be locally resolved on site during construction. Figure 1 below shows a sample for a major utility clash report that requires a design change.

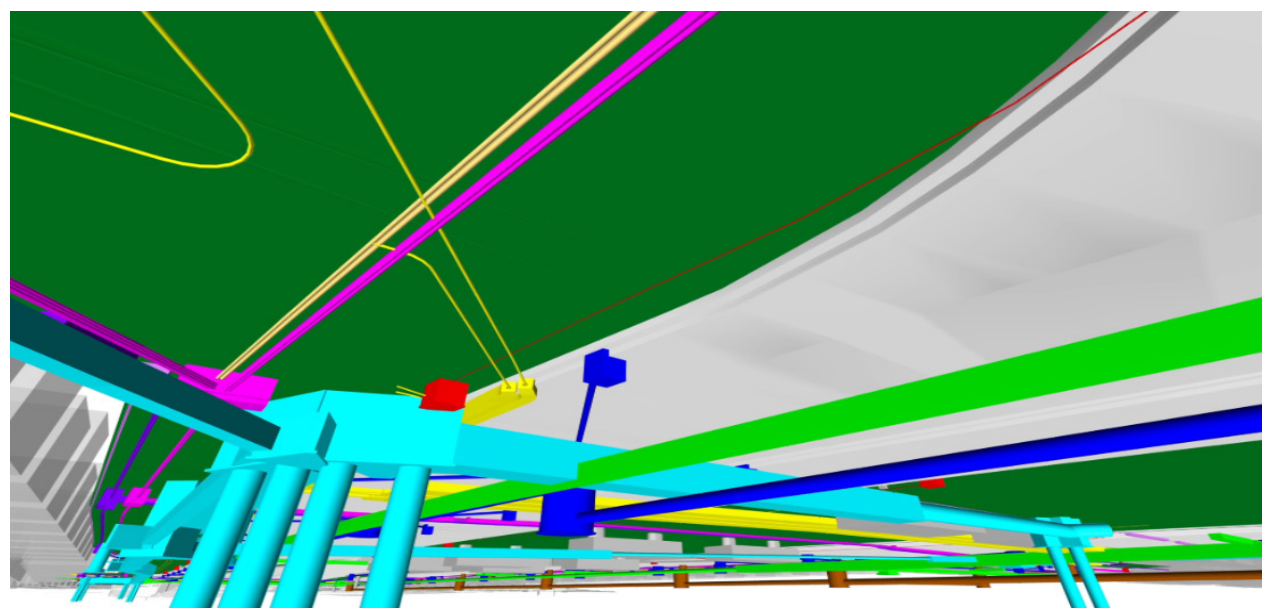

Figure 1: A sample utility clash report from BIM

\subsection{Risk management plan}

Banaitiene \& Banaitis (2012) as per APA, "risk management is probably the most difficult aspect of project management. A project manager must be able to recognise and identify the root causes of risks and to trace these causes through the project to their consequence."

Risks were defined for the project with their probability \& impact/consequences during brain storming sessions to create the risk register. Based on the P-I Score of each risk, they were categorized as Red Zone, Amber Zone and Green Zone.

- All Risks falling in the Red Zone are treated very carefully by providing risk response plan for each risk. The risk response plans are detailed because the risk response plan could cause some secondary risks. The secondary risks are included in the risk register as secondary risks.

- Risks to be monitored are those falling in the Amber Zone, if during monitoring such risks move to the Green Zone then they will be acceptable but if they move to the Red Zone then they are not acceptable and must be treated.

- Acceptable risks are those falling in the Green Zone.

Risk assessment was carried out on the overall process of risk identification, risk analysis and risk evaluation. Risk treatment carried out to develop strategies and action plans to manage risks as shown in Table 1 below.

Assigned risk manager to continuously manage the risks in the project. Risk register is in the agenda in the weekly progress meeting discussions and the project manager makes sure that all the engineers have input to the risk management in the project. 
Table 1: Sample risk register format

\begin{tabular}{|c|c|c|c|c|c|c|c|c|c|c|c|c|c|c|c|c|}
\hline Risk ID & $\begin{array}{l}\text { Risk } \\
\text { Type }\end{array}$ & $\begin{array}{l}\text { Risk } \\
\text { Category }\end{array}$ & $\begin{array}{c}\text { Risk } \\
\text { Description }\end{array}$ & Risk Owner & Status & Prob & Impact & $\begin{array}{l}\text { Risk } \\
\text { Score }\end{array}$ & $\begin{array}{l}\text { Mitigation } \\
\text { Action }\end{array}$ & $\begin{array}{l}\text { Mitigation } \\
\text { Owner }\end{array}$ & \begin{tabular}{|c|} 
Mitigation \\
Action \\
Date \\
\end{tabular} & $\begin{array}{c}\text { Progress } \\
\text { Complete }\end{array}$ & Prob & Impact & $\begin{array}{c}\text { Risk } \\
\text { Score }\end{array}$ & $\begin{array}{c}\text { Risk } \\
\text { Expiry } \\
\text { Date }\end{array}$ \\
\hline $\begin{array}{c}\text { Risk- } \\
\text { DN016-P00-14298 }\end{array}$ & Risk & Commercial & \begin{tabular}{c|} 
The Project \\
May Suffer \\
delay and \\
disruption \\
to expected \\
variation \\
orders \\
\end{tabular} & $\begin{array}{c}\text { Dennis } \\
\text { Rush (GEC/ } \\
\text { PMC) }\end{array}$ & Open & 3 & 4 & 12 & $\begin{array}{c}\text { Continuous } \\
\text { coordination } \\
\text { meeting with } \\
\text { GEC. For } \\
\text { any changes } \\
\text { in scope }\end{array}$ & $\begin{array}{l}\text { Dennis } \\
\text { Rush } \\
\text { (GEC/ } \\
\text { PMC) }\end{array}$ & $30-06-17$ & $90 \%$ & 2 & 1 & 2 & 31 \\
\hline
\end{tabular}

\subsection{Stakeholder management plan}

The project management team identified both internal and external stakeholders of the project in order to determine the project requirements and expectations of all parties involved. A sample of the stakeholder register is shown in Table 2 below.

A dedicated stakeholder manager is appointed to identify and manage the stakeholder issues without affecting the project performance. Although major efforts are done in this regard, many stakeholders residing nearby the construction area are affected negatively on the project execution due to the nature of the project and time constraints. The supervision consultant and the client are also directly involved in managing the stakeholders but ultimately impacted the project. However, the project management can strongly say that further delays were mitigated with the implementation of regular stakeholders meetings, and manage accordingly based on their requirements. This is a lesson learnt for the project team and also for the client.

Table 2: Sample of stakeholder register

\begin{tabular}{|c|c|c|c|c|c|c|c|c|c|c|c|c|c|c|c|c|c|}
\hline Issued & Stakcholdder & 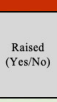 & 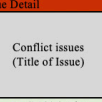 & Typo & $\begin{array}{c}\text { Date } \\
\text { Raised }\end{array}$ & 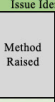 & 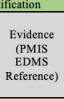 & 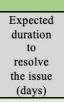 & 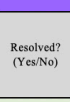 & $\begin{array}{c}\text { Dative } \\
\text { Resolved }\end{array}$ & $\begin{array}{l}\text { Method } \\
\text { Rasisc }\end{array}$ & 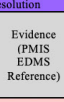 & 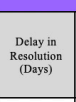 & 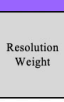 & $\begin{array}{c}\text { Contatcter } \\
\text { Noters }\end{array}$ & $\mid \begin{array}{l}\text { GEF } \\
\text { Notess }\end{array}$ & $\begin{array}{l}\text { PMC } \\
\text { Notes }\end{array}$ \\
\hline & $\begin{array}{l}\text { PWA } \\
\text { Public } \\
\text { Realim }\end{array}$ & Yes & 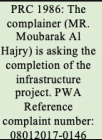 & PRC & 0220322017 & Email & & 1 & Yos & 03030322017 & Email & & 0 & 1 & & & \\
\hline
\end{tabular}

\subsection{Handing over plan}

Handing over of any project is the most hardest and lengthy process among all other processes of the project life cycle. Therefore, the target of the project management was to obtain stakeholders' early acceptance of the project. This meant that all stakeholders accept that the work has been completed in accordance with the project specifications and parameters within the agreed timeframe. In order to make this go smoothly, the stakeholder and project manager must have a well-documented criteria of performance, in place from the beginning of the project. This information should be documented in the project handing over plan which should include all changes requested through the life of the project.

The project management insisted to have a handing over plan from the beginning of the project and assigned a dedicated handing over manager with required resources and mobilized them at the very early stage of the project.

The handing over team identified all the handing over procedures and the required documentation with the client. The team has prepared a detailed program for handing over, identifying all the end users of the project. 
The project has utilized the internal software tool ATLAS which is linked with BIM model. The dedicated team decodes all the RFI tags to the BIM elements and identifies the lags time to time in coordination with the QA/QC team to resolve the issues if any arise in this regard.

\section{CONCLUSION}

Although the construction work was completed on time with opening roads to the traffic, the closing of the project was very time consuming, due to the handover process and procedure. As a way forward and as part of continues development in PWA RPD, new "construction enhancement contracts" call for the handing over to be completed within the project completion date by adding KPIs. Moreover the zone delivery takes into consideration the hand over time. This was agreed with PWA asset affairs, to streamline the process and reduce and risk of delay.

\section{RECOMMENDATIONS}

The following is recommended to avoid delays in the handing over process:

1) To identify project end-users and list their requirements including the detailed procedures on the list of handing over documents. This will vary from each end-user.

2) To have a contract handing over program binding with the all the end users. This should also dictate the approval durations and approval cycles.

3) To implement and adopt BIM for the handing over. This will simplify the process of documentation and have proper control on the handing over of RFIs, As-built drawings documentation.

4) The paper work of the handing over should be reduced. This is only possible if all the project end users will implement the BIM technology as a procedure in their system.

\section{REFERENCES}

Banaitiene \& Banaitis (2012). Risk management in construction projects, INTECH.

Salman Azhar (2011). Building Information Modeling (BIM): Trends, benefits, risks, and challenges for the AEC industry. Leadership Manage. Eng., 11(3): 241-252.

Sean, P. Pellegrino (2018). Introduction to CII's advanced work packaging - An industry best practice. Long International, Inc. 